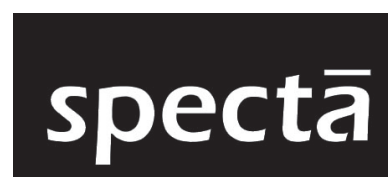

Journal of Photography,

Arts, and Media

Volume 2 Nomor 1

Mei 2018: 69-80

\section{FOTO PRODUK AMANDA GRIYA KEBAYA DENGAN ELEMEN PENDUKUNG BANGUNAN CAGAR BUDAYA DI YOGYAKARTA}

Tyas Afrian

Edial Rusli ${ }^{1}$

Adya Arsita ${ }^{2}$

Fakultas Seni Media Rekam

Institut Seni Indonesia (ISI) Yogyakarta

Surel: edial_rusli@yahoo.com

\begin{abstract}
Abstrak
Kebaya yang dulu mendapat sorotan sebagai pakaian kuno kini menjadi pakaian yang modern dan modis. Melalui media fotografi fashion, akan menarik apabila baju kebaya modifikasi dapat divisualisasikan dengan latar belakang bangunan cagar budaya di Yogyakarta sebagai elemen pendukung sehingga memberikan kesan tersendiri bagi para penikmat seni. Fotografi fashion dipilih karena mampu menampilkan produk yang dijual. Dalam karya ini, tantangan yang menarik adalah eksekusi dengan menyatukan kebaya yang modern dengan latar pemotretan berupa bangunan cagar budaya di Yogyakarta, terlebih apabila detail kebaya dapat jelas terlihat. Untuk itu, dilakukan serangkaian metode untuk menggali data yaitu observasi, studi pustaka, dan wawancara. Dlam penciptaan karya dilakukan melalui tahapan ini, yaitu kontemplasi, pravisualisasi, persiapan, eksekusi, hingga pascaproduksi. Karya foto produk dari Griya Amanda Kebaya dalam fotografi fashion ini tidak sekadar menampilkan busana secara visual, tetapi terdapat muatan informasi tentang kebaya dan bangunan yang dipakai. Melalui karya-karya ini didapatkan bahwa kebaya yang disandingkan dengan bangunan cagar budaya menjadi lebih menarik dan mudah dalam menyampaikan atau menanamkan brand image kepada audience, sehingga audience tertarik untuk menyewa atau membuat kebaya di Amanda Griya Kebaya.
\end{abstract}

Kata kunci: Amanda Griya Kebaya, kebaya, cagar budaya, fotografi fashion

\begin{abstract}
Product Photography of Amanda Griya Kebaya with Cultural Heritage Buildings in Yogyakarta as Supporting Elements. Kebaya (a traditional Javanese blouse worn by women) which was considered as an old-fashioned dress, now becomes a modern and stylish dress, of course through a long and uneasy journey. With the medium of fashion photography, it will be interesting if the modified kebaya dress can be visualized with the background of cultural heritage buildings in Yogyakarta as supporting elements, so that it will give a certain impression for art enthusiasts. Fashion photography was chosen because it can show the product that will be sold. Fashion photography aims to make the designed dress looks interesting so that people would be eager to buy it. In this project, the challenge to combine the modern kebaya with the background of cultural heritage buildings in Yogyakarta is interesting to be executed, especially if the details of the kebaya can be seen clearly. To answer that challenge, a series of processes was carried out with some methods namely observation, literature review, and also interview. The steps that were carried out in this project were started with the description of the kebaya dress of Amanda Griya Kebaya, contemplation, pra-visualization, preparement, excecution, until post-production. The result came with the photographs of Amanda Griya Kebaya's product with the supporting element of cultural heritage buildings in Yogyakarta. In the implementation, it was not only creating an artwork that shows the dress visually, but also adding a content of information about the kebaya itself and the buildings used as the backgrounds. Through all of the photoworks, it can be concluded that the kebaya dress combined with cultural heritage building is more interesting and it is also easier to communicate or advertise the brand image to the audience, so that the audience will be interested to rent or order kebaya dress in Amanda Griya Kebaya.
\end{abstract}

Keywords: kebaya, cultural heritage buildings, fashion photography, griya

\footnotetext{
${ }^{1}$ Dosen di Program Studi Fotografi, Fakultas Seni Media Rekam, Institut Seni Indonesia Yogyakarta.

${ }^{2}$ Dosen di Program Studi Fotografi, Fakultas Seni Media Rekam, Institut Seni Indonesia Yogyakarta.
} 


\section{PENDAHULUAN}

Indonesia kaya akan tradisi dan budaya yang sangat beragam. Tidak terkecuali pakaian adat yang masih dijaga dan dilestarikan hingga saat ini. Keragaman pakaian adat tersebut tersebar di berbagai daerah, salah satunya adalah kebaya. Kebaya adalah busana yang dikenakan wanita Indonesia dalam kehidupan seharihari pada zaman dahulu. Pada era Kartini kebaya hanya dilihat seperti baju daerah biasa yang kombinasi pemakaiannya diselaraskan dengan kain batik panjang (Hasyim, 2009). Sejarah munculnya kebaya dimulai dari masyarakat di Jawa yang biasa memakai kebaya sebagai busana tradisional dalam acara-acara tertentu. Namun, seiring berkembangnya fashion, kebaya menjadi "busana nasional" Indonesia.

Kebaya melekat hampir pada setiap acara-acara besar dalam keseharian masyarakat Indonesia, misalnya pada saat kelulusan atau wisuda, acara lamaran atau pernikahan. Kebaya sudah merambah ke berbagai daerah di Indonesia, Yogyakarta adalah salah satunya. Di Kota Yogyakarta yang memang mempunyai budaya berbusana kebaya untuk para perempuannya tentunya memiliki banyak perancang kebaya. Amanda Griya Kebaya adalah salah satu yang juga ada di Yogyakarta, beralamatkan di Jalan Samirono No. 193, Yogyakarta. Griya kebaya yang berdiri sejak 2003 ini adalah sebuah butik dan salon yang memiliki kebaya dengan ciri khas tersendiri, yaitu dengan warna payetan yang memadukan dua warna dan tambahan "ekor" berpayet. Kebaya milik Amanda Griya Kebaya lebih mengarah pada gaya anak muda bernuansa modern atau lebih sering disebut kebaya modifikasi.

Yogyakarta selain terkenal dengan bermacam jenis kebaya juga terkenal dengan berbagai bangunan peninggalan pada masa penjajahan atau biasa disebut heritage. Dalam kamus Inggris-Indonesia susunan John M. Echols dan Hassan Shadily, heritage berarti warisan atau pusaka. Pengertian heritage yang sesungguhnya cukup luas, UNESCO memberikan definisi bahwa heritage sebagai warisan (budaya) masa lalu, apa yang saat ini dijalani manusia, dan apa yang diteruskan kepada generasi mendatang. Kebanyakan orang belum begitu tahu bahwa heritage tidak hanya sebuah peninggalan bersejarah. Pada Piagam Pelestarian Pusaka Indonesia yang dideklarasikan di Ciloto 13 Desember 2003, Pusaka (heritage) Indonesia meliputi Pusaka Alam, Pusaka Saujana, dan Pusaka Budaya. Kota Yogyakarta selain terkenal sebagai kota pelajar juga terkenal dengan tempat wisata yang bernuansa bangunan bersejarah.

Bangunan cagar budaya di Yogyakarta dewasa ini semakin terdesak oleh perkembangan pembangunan. Oleh karena itu, ada beberapa bangunan cagar budaya yang diperhatikan oleh pemerintah dan mendapat perawatan dan ada juga yang tidak begitu diperhatikan. Beberapa bangunan cagar budaya juga ada yang difungsikan atau dimanfaatkan, misalnya sebagai museum, tempat wisata, bank, dan kantor pos, namun ada juga yang sudah dari dahulu difungsikan sebagaimana mestinya seperti masjid, gereja, dan klenteng/vihara.

Penciptaan karya fotografi fashion ini diharapkan mampu memperkaya pengalaman visual dan menjadi referensi yang bisa memperkaya khazanah penciptaan fotografi. Penciptaan karya fotografi ini diharapkan bisa lebih diperhatikan karena menampilkan kebaya dengan latar belakang bangunan cagar budaya serta menampikan detail kebaya dengan lokasi sudut-sudut bangunan cagar budaya sehingga tetap memperkuat nilai busana yang dijual. Pembuatan 
karya foto ini menggunakan pendekatan fotografi fashion, dengan memerhatikan pencahayaan, komposisi, estetika, sesuai dengan ide penciptaan karya fotografi ini. Lokasi yang dijadikan pemotretan tentunya bangunan cagar budaya di Yogyakarta. Akan tetapi, karena banyaknya bangunan cagar budaya di Yogyakarta, maka dipilih sekitar beberapa bangunan cagar budaya antara lain Tugu Yogyakarta, Pasar Beringharjo, Benteng Vredeburg, situs (pasrangahan) Warungboto, Taman Sari, rumah-rumah limasan dan joglo di daerah Kotagedhe dan tempat-tempat lainnya yang dianggap mampu mewakili bangunan cagar budaya di Yogyakarta.

Pemotretan produk kebaya sudah biasa dilakukan untuk keperluan komersial. Pemotretan bangunan cagar budaya juga sudah seringdilakukan, tetapi masih sebatas untuk keperluan pariwisata. Penciptaan karya fotografi ini mencoba menggunakan bangunan cagar budaya sebagai elemen pendukung dalam pemotretan produk kebaya milik Amanda Griya Kebaya. Hal ini dilakukan karena belum pernah ditemukan analisis atau penciptaan karya fotografi dengan perpaduan serupa, yaitu antara kebaya dengan bangunan cagar budaya dalam fotografi fashion, maka ide penciptaan dirumuskan sebagai berikut, (1) bagaimana memaksimalkan tampilan bangunan cagar budaya di Yogyakarta dalam penciptaan karya fotografi fashion produk Amanda Griya Kebaya dan (2) bagaimana memvisualisasikan detail motif produk Amanda Griya Kebaya dalam penciptaan karya fotografi fashion.

Penciptaan karya foto ini ditujukan untuk memvisualisasikan detail produk Amanda Griya Kebaya dalam penciptaan karya fotografi fashion. Tujuannya adalah agar bisa menambah wawasan tentang cagar budaya kota Yogyakarta, serta menambah inspirasi dalam perkembangan kebaya yang semakin menarik.

Ide yang timbul dari pengalaman dikatakan sebagai pengalaman empiris, ide yang timbul dari dalam diri dikatakan sebagai intrinsik sedangkan dari luar adalah ekstrinsik. Ide penciptaan fotografi ini berawal dari melihat dan mengalami sendiri ketika melakukan pemotretan upacara pernikahan, melihat berbagai macam kebaya dan perkembangannya yang kian hari semakin menarik. Namun, sebelum melihat dan mengalami sendiri, pernah juga mengamati secara tidak langsung, yaitu ketika melihat hasil foto dari kakak kandung penulis yang dulu juga pernah memfoto sebuah acara pernikahan. Dari situ secara tidak langsung telah melakukan pengamatan dengan hasil foto pernikahan yang tentunya juga menampilkan berbagai macam kebaya dari beberapa upacara pernikahan.

Kebaya yang akan divisualisasikan dengan elemen pendukung bangunan cagar budaya di Yogyakarta kali pertama tercetus ketika melihat perkembangan pembangunan kota yang semakin pesat ditambah semakin ramainya wisatawan yang berdatangan ke Yogyakarta yang juga memunculkan berbagai hotel baru yang sedikit menyita perhatian pemandangan akan bangunan tua di Yogyakarta. Dalam Undang-Undang Cagar Budaya dijelaskan bahwa sebuah cagar budaya ditetapkan apabila memiliki arti khusus bagi sejarah, ilmu pengetahuan, pendidikan, agama, dan/atau kebudayaan, beberapa bangunan cagar budaya di Yogyakarta tentunya juga dimanfaatkan sebagaimana dalam undangundang tersebut dikatakan, misal sebuah bangunan cagar budaya yang dijadikan tempat wisata yang bernilai budaya atau sejarah, salah satu contoh pemanfaatan dalam bidang kebudayaan. 
BangunancagarbudayadiYogyakarta tentunya sangat banyak, namun yang akan dipakai dalam penciptaan ini adalah bangunan cagar budaya yang menjadi ikon Yogyakarta. Dengan menjadikan bangunan cagar budaya yang bisa dikatakan sudah melekat dengan Yogyakarta sebagai latar belakang pemotretan kebaya, bangunan cagar budaya di Yogyakarta yang sudah menjadi ikon Yogyakarta tersebut akan ikut menjadi brand image yang tersampaikan kepada audience. Faktor-faktor tersebutlah yang mendasari adanya rumusan ide dalam penciptaan ini. Berikut kajian sumber visual untuk penciptaan karya foto produk Amanda Griya Kebaya dalam Fotografi Fashion. Agam Bajradaram adalah salah satu alumnus Program Studi Fotografi, Fakultas Seni Media Rekam, Institut Seni Indonesia Yogyakarta yang dahulu pernah membuat sebuah fotografi fashion bertemakan kebaya modern. Penciptaan fotografi fashion dengan kebaya modern milik Agam berfokuskan pada detail baju. $\mathrm{Hal}$ ini dapat dilihat dari penggunaan tata cahaya dengan intensitas cahaya yang selalu berpusat pada baju kebaya. Dalam penciptaan karya fotografi tersebut tampak kebaya modern yang difoto dengan tempat yang bisa dibilang bernuansa khas Jawa. Akan tetapi, tempat-tempat yang digunakan masih belum spesifik terlihat di mana tempat tersebut karena pengambilan foto dengan sudut pengambilan dan komposisi yang selalu terpusat pada model dan baju yang dikenakan.

Karya Agam Bajradaram (Bajradaram, 2010) selain menjadi tinjauan karya juga menjadi foto acuan dalam penggambilan detail baju kebaya. Karya tersebut menjadi acuan pada bagian pengambilan detail baju kebaya terutama dengan tata pencahayaan yang dapat menampilkan dimensi baju dengan bangunan di sekitarnya. Meskipun karya yang akan diangkat nantinya juga tentang kebaya, ada perbedaan dalam penciptaan fotografi fashion produk Amanda Griya Kebaya. Dalam penciptaan fotografi fashion ini nantinya akan menambahkan bangunan cagar budaya yang menjadi ikon di Yogyakarta seperti Tugu, Bringharjo, Tamansari, dan tempat-tempat lainya sebagai elemen pendukung sehingga lokasi yang akan digunakan lebih spesifik.

Shelton Multer adalah fotografer yang telah berada dalam dunia fotografi lebih dari 30 tahun. Shelton Multer bekerja di banyak bidang industri fotografi. Selain sebagai fotografer, Shelton juga sebagai mentor, guru, dan penulis. Shelton adalah seorang fotografer yang fokus pada fotografi wedding, namun Shelton juga terkadang memfoto yang lain seperti portrait dan landscape. Karya yang menjadi tinjauan milik Shelton tersebut adalah salah satu karyanya yang termasuk dalam kategori portrait. Dalam karyanya tersebut Shelton menggunakan white balance tungsten untuk mendapatkan nuansa biru pada background. Dalam objeknya Shelton menerangi dengan flash eksternal yang ditambahkan filter color temperature orange (CTO) sehingga menjadikan objek tetap pada nuansa normal atau pada white balance daylight. Karya milik Shelton Muller (Muller, 2011) tersebut selain menjadi tinjauan karya juga akan menjadi foto acuan dalam hal teknis penggunaan white balance dan filter pada flash eksternal yang nantinya juga akan dilakukan dalam penciptaan karya tugas akhir ini. 


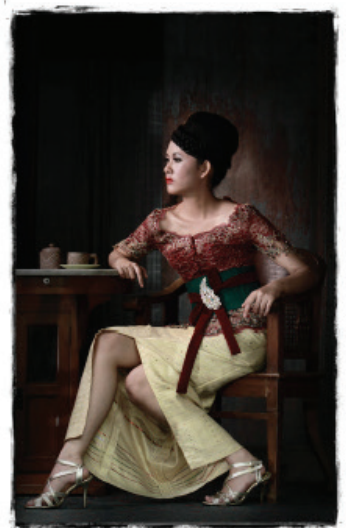

Gambar 1

(1) \& (2) Karya Agam Bajradaram (Bajradaram, 2010)

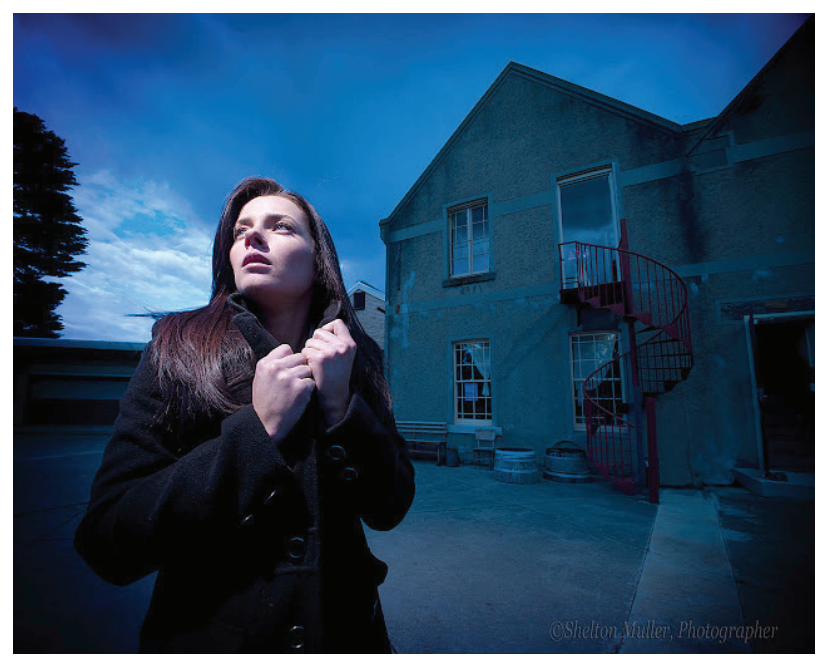

Gambar 3. Karya Shelton Muller Sumber: http://sheltonmuller.blogspot. co.id/2011/08/working-with-flash.html diakses pada tanggal 5 Juni 2017 pukul 23.39 WIB.

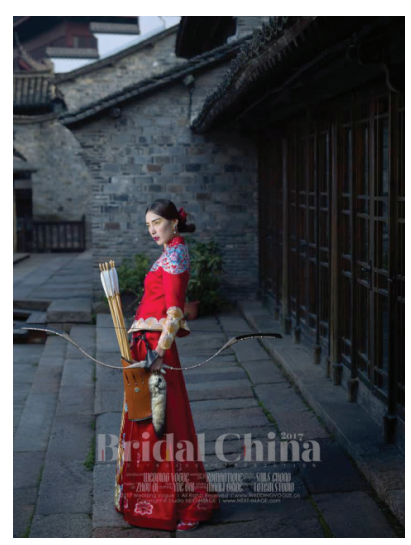

Gambar 4

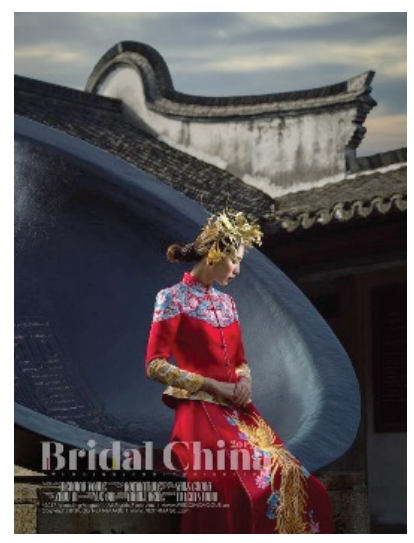

Gambar 5
(4) \& (5) Karya: Sail Chong Sumber: https://www.facebook.com/pg/ StudioNextImage/photos / ?ref=page_internal diakses pada tanggal 17 April 2017 pukul 21.17 WIB
Sail Chong adalah seorang pendiri, kepala sekaligus fotografer dari NEXTIMAGE Group atau yang biasa dikenal dengan Studio-Next Image. Bertempatkan di Hong Kong, Cina Studio-Next Image mengerjakan foto komersial yang berfokuskan pada fashion dan prewedding, namun dalam pengerjaannya studio-Next Image tidak hanya berada di China saja bahkan sampai Jepang dan beberapa negara lainnya. Sail Chong yang juga seorang fotografer Studio-Next Image menggunakan alat dari Hasselblad dan Broncolor. Karya-karya dari Sail Chong banyak menggunakan filter Neutral Density (ND) dengan pencahayaan yang lembut dan juga kontras. Karya yang bertemakan Bridal China tersebut menampakkan seorang model menggunakan sebuah busana cina yang dimodifikasi dengan latar belakang bangunan kuno, cahaya yang digunakan kebanyakan dari samping sehingga lebih menimbulkan dimensi. Karya Sail Chong selain menjadi tinjauan karya juga menjadi foto acuan dari segi penggambilan foto dengan latar belakang bangunan yang tetap menonjolkan objeknya.

Tinjauan-tinjauan karya tersebut didukung pula oleh referensi-referensi berikut yang menjadi landasan penciptaan karya foto produk Griya Amanda Kebaya. Fotografi sebagai medium komunikasi visual dapat menyampaikan pesan yang diinginkan oleh pembuatnya, termasuk fotografi komersial yang mengarah pada kepentingan komersial atau pemasaran dengan tujuan untuk mendapatkan keuntungan secara materi. Fotografi komersial digunakan sebagai media atau perantara antara klien dengan konsumen. Seorang fotografer komersial dituntut untuk dapat memenuhi keinginan klien yang bertujuan untuk mendapat kepuasan dari target konsumen yang dituju, 
biasanya melalui foto, tanda, dan pesan yang diberikan.

Fotografi fashion adalah salah satu genre fotografi yang menekankan pada produk busana dan aksesorisnya (Abdi, 2012). Dari klien yang ingin menampilkan keinginannya dalam sebuah karya foto, seorang fotografer harus bisa mengolah pesan tanda yang ada sebagai sarana/ jembatan komunikasi. Karya fotografi dapat dimanfaatkan sebagai medium komunikasi, medium komunikasi di sini adalah untuk dapat memengaruhi konsumen yang tak lepas dari tampilannya sebagai elemen ilustrasi dengan nilai estetisnya (Soedjono, 2007). Perkembangan fotografi fashion untuk menyampaikan pesan juga sudah cukup luas. Fashion photography tidak lagi hanya memamerkan gambar model yang cantik dengan baju yang bagus, kini fashion photography lebih pada menjual image. Gambar dengan konsep yang kuat dan cerita yang menarik menjadi titik utama foto fashion saat ini (Adimodel, 2009).

Penciptaan karya ini memvisualkan kebaya milik Amanda Griya Kebaya dengan elemen pendukung bangunan cagar budaya di Yogyakarta melalui fotografi fashion yang dirasa dapat menyampaikan pesan visual tentang pelestarian budaya selain tentu saja 'menjual' produk kebaya dari Amanda Griya Kebaya. Tentu saja aspek-aspek pendukung lainnya juga akan digunakan seperti komposisi dan estetika fotografi. Komposisi dalam bidang seni rupa dan fotografi dapat diartikan sebagai cara penempatan objek dalam bidang gambar dengan memanfaatkan faktor-faktor komposisi, sedemikian rupa sehingga benar-benar dapat menjadi titik pusat perhatian (focus of interest) bagi orang yang melihatnya (Ardiansyah, 2005). Selain itu, komposisi tidak lain dari seni menempatkan gambar benda- benda dan menyusun garis-garis dalam batas-batas bidang gambar sedemikian rupa, sehingga dapat menyatakan dengan jelas apa yang terkandung di dalamnya, serta menyenangkan untuk dipandang (Suleiman, 1977).

Komposisi memang perlu diperhatikan, yaitu menempatkan point of interest dengan benar, namun perspektif pada saat pengambilan gambar perlu diperhatikan. Perspektif adalah pengaruh panjang fokal lensa yang dapat membuat latar belakang tampak lebih dekat atau lebih jauh dari objek utama. Pada lensa tele, latar belakang akan tampak lebih dekat dari objek, sedangkan pada lensa wide latar belakang akan tampak lebih jauh dari objek (Adimodel, 2009). Perspektif dipengaruhi seberapa jauh atau dekat jarak kamera ke objek dan seberapa jauh atau dekat jarak objek dengan latar belakangnya (Ardiansyah, 2005). Penciptaan karya tugas akhir ini yang menggunakan latar belakang bangunan cagar budaya sebagai elemen pendukung perlu memerhatikan komposisi dan perspektif pengambilan gambar, yaitu antara latar belakang dan objek yang diletakkan pada komposisi $1 / 3$ bidang (rule of third). Penggunaan lensa wide angel juga sebagai sarana pendukung dalam penciptaan ini, yaitu untuk menampilkan bangunan yang akan menjadi elemen pendukung.

Estetika dalam fotografi juga perlu diperhatikan karena menyangkut dengan isi dalam sebuah karya. Estetika fotografi dibagi dalam dua wilayah (Soedjono, 2007), yakni estetika pada tataran ideasional dan estetika pada tataran teknikal. Seperti dijelaskan Irwandi \& M. Fajar Apriyanto (Apriyanto, 2012) maksud tataran ideasional adalah pengimplementasian media fotografi sebagai wahana berkreasi dan menunjukkan ide serta jadi diri 
seorang fotografer. Keinginan untuk menunjukkan eksistensi dan ide pribadi seorang fotografer tercermin dalam konsep dan pendekatan estetis yang dipilihnya.

Tataran ideasional tersebut yang mendasari apa yang akan digambarkan atau dibuat oleh seorang fotografer. Biasanya tataran ideasional dekat dengan jati diri seorang fotografer yang ingin menunjukkan hasil kerjanya dengan memvisualisasikanya melalui teknik fotografi. Tentunya ide juga berkaitan denganobjek, fotograferatau penciptakarya, alat atau kamera, proses editing, dan juga penyajian akhir sebuah karya. Penciptaan karya tugas akhir ini melakukan beberapa tahapan dalam perwujudan ide, dari menentukan jumlah kebaya dan jenisnya, konsultasi dengan makeup artist sekaligus hair stylist, menentukan model yang akan dipakai, observasi ke lokasi yang akan digunakan dalam memvisualisasikan ide agar lebih mempermudah saat melakukan pemotretan.

Selain pada tataran ideasional, wacana estetika fotografi juga meliputi halhal yang berkaitan dengan berbagai macam teknik baik itu yang bersifat teknikal peralatan maupun yang bersifat teknik praxis-implementatif dalam menggunakan peralatan yang ada guna mendapatkan hasil yang diharapkan (Soedjono, 2007). Tataran teknikal ini tidak hanya berhenti pada saat pemotretan, namun masih tersedia ruang kreatif bagi fotografer untuk bereksplorasi dan eksperimentasi pada pascapemotretan. Tataran ideasional dan teknikal saling berkaitan dan menjadikannya sebuah jembatan untuk seorang fotografer dalam menciptakan sebuah karya (Apriyanto, 2012).

Penciptaan karya ini melalui beberapa proses, yaitu bereksperimen dalam pemotretan, karena pemotretan semuanya dilakukan di luar ruangan maka diperlukan cahaya tambahan sebagai pengisi pada objek, kehadiran flash sebagai sumber cahaya merupakan sarana bantu yang mendukung untuk menghasilkan gambar objek dalam fotografi. Eksperimen dilakukan dengan mengubah WB (white balance), yaitu satuan suhu cahaya yang diukur dengan derajat Kelvin. Di luar ruangan, flash eksternal yang dipadukan dengan sinar matahari memiliki suhu sekitar 5000-5500K, flash eksternal biasanya memiliki suhu yang hampir sama dengan cahaya matahari.

Saat white balance (WB) diterapkan pada pengaturan tungsten, maka diperlukan filter warna orange untuk menyeimbangkan warna cahaya, perpaduan dua sumber cahaya yang berbeda ini disebut mix color. Dengan menurunkan atau menaikkan derajat kelvin pada kamera yang digunakan sehingga menciptakan nuansa yang kebiruan atau kekuningan, tentunya objek akan ikut menjadi biru atau kuning. Namun objek dalam penciptaan ini haruslah berwarna netral karena akan menjadi point of interest, flash eksternal yang ditambahkan filter colour temperature orange (CTO) dan colour temperature blue (CTB) akan memberikan warna netral pada objek tergantung pada white balance (WB) yang akan digunakan. Setelah proses pemotretan selesai, pengolahan juga dibutuhkan dalam penciptaan karya ini untuk lebih mematangkan hasil foto yang diinginkan.

Penciptaan karya ini menggunakan pendekatan teori representasi untuk mengulas karya foto yang dihasilkan. Representasi dapat diartikan jelasnya sebagai penggunaan tanda yang menghubungkan, menggambarkan, memotret atau memproduksi suatu yang dapat dilihat, diindera, dibayangkan, atau 
dirasakan dalam bentuk fisik tertentu (Danesi, 2012). Representasi membuat suatu hubungan antara makna dan bahasa dalam budaya yang merupakan bagian penting di mana makna yang dihasilkan dipahami oleh anggota masyarakat dengan latar budaya yang sama. Ide atau konsep dari suatu hal yang dimiliki dalam pikiran menimbulkan suatumaknayangtidakdapat dikomunikasikan tanpa bahasa, karena suatu makna dibangun menggunakan konsep (ide) dan tanda (Hall, 2003). Oleh karena itu, konsep dan tanda menjadi bagian penting yang digunakan dalam proses kontruksi atau produksi makna. Jadi, representasi adalah suatu proses untuk memproduksi makna dari konsep yang ada dalam pikiran melalui bahasa, dalam konteks ini bahasa yang dimaksud adalah bahasa visual. Maka pemaknaan ulang akan sesuatu seutuhnya kembali lagi kepada individu yang bersangkutan. Dengan latar belakang yang sama dan dengan pengalaman empiris yang sama maka akan didapatkan pemahaman yang sama pula. Beberapa aspek tersebut yang menjadikan dasar dalam proses produksi dan pasca-produksi penciptaan karya tugas akhir ini.

\section{Metode Penciptaan}

Perkembangan zaman yang semakin maju juga membuat manusia semakin mengikutinya entah dengan sadar atau pun tidak sadar. Fashion manjadi bagian dalam kehidupan manusia yang semakin berkembang. Kebudayaan yang dipertahankan juga mengikuti perkembangan zaman. Kebaya adalah sebuah busana yang masih dijaga dan juga mengikuti perkembangan zaman dengan berbagai modifikasi yang menjadikannya busana yang tampil lebih anggun dan indah. Ide memvisualisasikan kebaya dengan latar belakang bangunan cagar budaya di Yogyakarta dengan beberapa bangunan yang memiliki cerita dan corak berbeda-beda akan mempunyai keunikan untuk diwujudkan dengan fotografi fashion.

Tahapan penciptaan ini dimulai dengan eksplorasi dan mengumpulkan data-data dari buku, artikel, jurnal, atau dari internet. Kemudian melakukan survei ke lokasi yang akan dipakai, tentunya di sini adalah bangunan cagar budaya yang akan digunakan. Survei juga dilakukan untuk mendapatkan informasi tentang izin lokasi yang akan digunakan. Setelah menentukan lokasi kemudian dicoba untuk mencari izin agar bisa melakukan pemotretan, maka tanggal pemotretan juga harus sudah direncanakan. Setelah lokasi ditentukan, pemilihan kebaya yang akan dipakai juga diperlukan. Dalam tahapan ini juga dilakukan pemilihan model yang akan diajak bekerja sama. Setelah menentukan model, kemudian dilakukan fitting kebaya dengan model yang akan memakainya, tentunya menjelaskan kepada model untuk pose, ekspresi dan gesture juga dilakukan agar membangun suasana nyaman dan saling percaya dengan model yang bisa berpengaruh pada saat produksi. Melakukan konsultasi dengan make up artist untuk menyesuaikan tampilan tata rias. Dikarenakan pemotretan dilakukan di luar ruangan, perencanaan juga dibutuhkan ketika melakukan pemotretan agar meminimalkan kesulitan yang ada. Perencanaan yang dilakukan seperti rapat dengan kru yang akan membantu, mempersiapkan alat-alat utama seperti kamera, tripot, flash, dan alat pendukung yang dibutuhkan.

Tahap selanjutnya adalah eksperimentasi. Tahapan ini juga bisa dikatakan sebagai proses perwujudan, namun masih dalam tahap mencari dan 
bereksperimen untuk menentukan hal apa yang akan menjadi pembeda dengan karya-karya lainya. Penciptaan karya foto ini selain menggabungkan kebaya dengan bangunan cagar budaya juga bereksperimen dalam hal teknis yang digunakan. Eksperimen dilakukan dengan mengubah white balance pada kamera sehingga color temperature menjadi turun atau naik. Tentunya hal tersebut juga akan mengubah color temperature pada model dengan kebaya yang menjadi fokus utama. Untuk itu, pada saat pemotretan flash yang digunakan ditambahkan filter CTO dan CTB untuk menjaga model dengan kebaya tetap pada nuansa normal.

Pemotretan yang dilakukan di luar ruangan dan juga memperlihatkan sisi bangunan cagar budaya yang dipakai, tentunya juga akan ada unsur visual berupa langit dalam karya. Dengan demikian, filter gradual neutral desity $(G N D)$ akan digunakan untuk menurunkan perbedaan intensitas cahaya antara langit dan daratan. Penggunaan filter GND ini bertujuan untuk lebih memudahkan pada saat melakukan pengolahan foto karena tidak perlu mengganti langit.

Tahap terakhir adalah perwujudan dalam bentuk karya. Tentunya dalam penciptaan karya rugas akhir ini proses produksi atau pemotretan dilakukan di luar ruangan, terkadang ada kendala yang membuat jadwal harus digantikan dengan yang lain. Tahan perwujudan atau produksi dilakukan kurang lebih selama dua bulan. Setelah itu, proses perwujudan tahap akhir ini adalah memilih foto untuk diolah menggunakan software Adobe Photoshop CS6. Pengolahan foto di sini termasuk dalam nilai estetis yang berhubungan dengan teknikal, yaitu pascapemotretan yang meliputi retouch foto dan menambah atau mengurangi objek pendukung dalam foto. Hasil foto yang sudah diolah tersebut dicetak ukuran $3 R$ atau $4 R$ untuk dikonsultasikan dengan dosen pembimbing. Setelah proses konsultasi dan pemilihan selesai foto yang terpilih dicetak pada kertas foto glossy ukuran 16R, 16Rs, dan 20Rs untuk penyajian akhir nantinya. Karya disajikan dengan pigura warna hitam polos, mounting warna putih dengan jarak $8 \mathrm{~cm}$ killing dan dengan kaca dof.

\section{PEMBAHASAN}

Karya foto yang berjudul "Istimewa" ini menghadirkan seorang model dengan kebaya yang memadukan warna unguputih dengan jarit bercorak ungu dan tambahan ekor panjang berlatar belakang tugu Yogyakarta yang menjadi ikon utama Kota Yogyakarta. Model dengan kebaya yang dipakainya merepresentasikan sosok yang kuat, menghadirkan kembali kebaya dengan modifikasi yang memberikan kesan kuat di zaman yang semakin berkembang, bahwa kebaya masih tetap menjadi busana yang bertahan bahkan berkembang menjadi busana yang anggun dan modern. Becak tradisional dan tugu putih yang berdiri kokoh memberikan kesan tambahan akan kekuatan budaya di zaman ini.

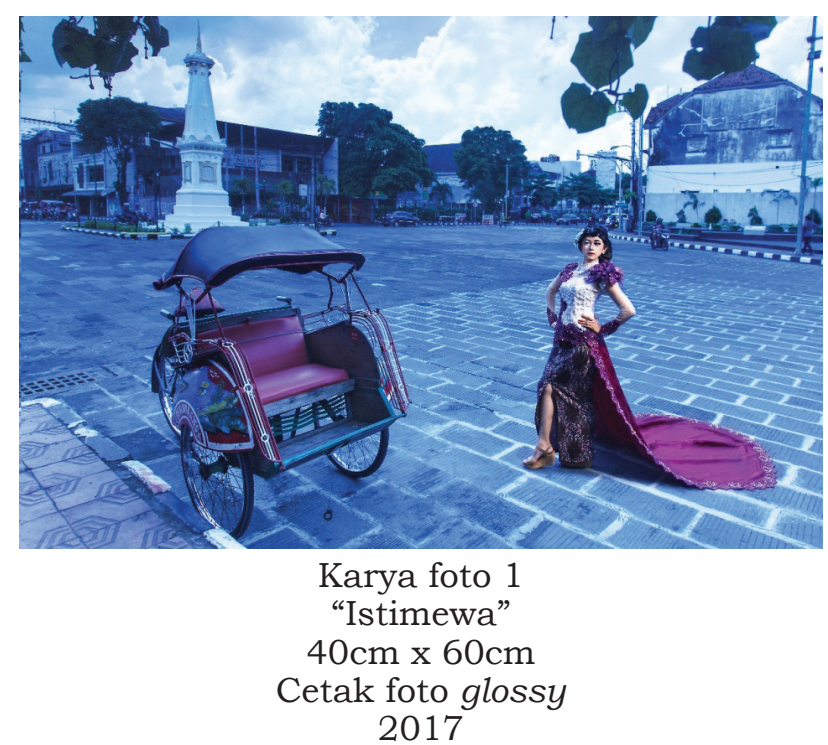


Proses pembuatan karya dilakukan pada saat pagi sehingga cahaya yang didapat tidak terlalu keras, namun dengan posisi sudut model yang membelakangi cahaya matahari sehingga tetap diperlukan tambahan flash. Flash ditempatkan pada posisi sudut sudut $45^{\circ}$ dan $315^{\circ}$ terhadap model. Posisi sudut sudut $45^{\circ}$ ditambahkan aksesoris payung putih transparan pada flash yang digunakan agar cahaya yang didapat lebih menyebar ke seluruh baju dan sebagian wajah model, sedangkan posisi sudut sudut $315^{\circ}$ flash yang digunakan tanpa tambahan aksesoris. Karya foto satu menggunakan white balance tungsten yang mengakibatkan nuansa pada foto menjadi biru, tetapi pada kedua flash ditambahkan filter CTO $1 / 4$ yang membuat model dengan kebaya tetap pada color temperature normal.

Karya yang berjudul "Lorong-Lorong" ini menghadirkan seorang model dengan kebaya dengan perpaduan warna yang hampir seimbang antara putih dan hijau. Putih yang mendominasi pada atasan dan jarit dengan tambahan hiasanyang berwarna hijau, sedangkan tambahan ekor panjang yang dominan berwarna hijau semua menyeimbangkan perpaduan antara dua warna tersebut. Karyaini merepresentasikan akan mitos tentang sebuah lorong bawah tanah yang akan terhubung dengan pantai selatan di Yogyakarta, namun sebenarnya dahulu tempat itu adalah sebuah masjid bawah tanah yang terdiri dari 2 lantai, pada masanya lantai 2 diperuntukkan untuk imam dan jemaah pria, sedangkan lantai dasar diperuntukkan untuk jemaah wanita. Model dengan kebaya yang berada di samping sebuah pintu menggambarkan ujung dari lorong, latar belakang bangunan yang melengkung dengan langit-langit yang pendek dengan nuansa kebiruan menggambarkan lorong yang berada di bawah tanah.

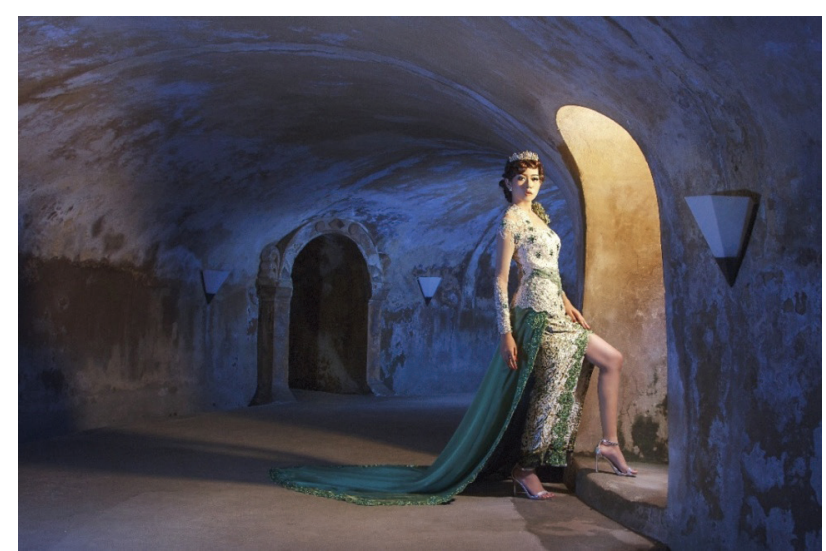

Karya foto 2.

"Lorong-Lorong"

$50 \mathrm{~cm} \mathrm{x} 75 \mathrm{~cm}$

Cetak foto glossy

2017

Proses produksi karya ini dilakukan pada saat sore hari dengan cahaya matahari yang sangat sedikit karena tertutup mendung dan lokasi yang berada di bawah tahan. Untuk menyiasati situasi tersebut, maka digunakan tiga buah sumber cahaya atau cahaya tambahan. Satu cahaya tambahan digunakan sebagai cahaya utama, yaitu pada posisi sudut $90^{\circ}$ dengan mobile light yang ditambahkan filter CTO $1 / 4$, pada posisi sudut ini tidak digunakan aksesoris tambahan, hanya saja flash sedikit diarahkan ke sisi atas (bouncing) dari lengkungan pintu yang berada di depan model. White balance pada karya ini menggunakan tungsten dengan tujuan membuat perbedaan atau percampuran antara beberapa sumber cahaya. Maka dari itu, pada posisi sudut $315^{\circ}$ digunakan flash yang diarahkan pada sisi kanan model sebagai cahaya pengisi atau fill-in dan untuk membentuk ruang pada tembok sisi depan bagian foto. Sementara itu, pada posisi sudut $135^{\circ}$ juga digunakan flash tanpa tambahan filter yang diarahkan pada tembok belakang untuk membangun ruang atau membentuk dimensi. Kedua flash tersebut tidak ditambahkan filter sehingga color temperature akan mengikuti white balance tungsten. Maka dari itu, perbedaan 
color temperature akan didapat dari mobile light yang ditambahkan filter CTO $1 / 4$ dan flash yang tanpa tambahan filter.

"Ayu" adalah judul yang dipilih untuk karya foto 20 ini. Ayu dalam bahasa Jawa yang memiliki arti cantik, menawan, dan anggun. Model yang mengenakan kebaya dengan perpaduan warna biru dan silver memberikan kesan cantik, menawan, dan anggun. Judul ayu dalam karya ini juga merepresentasikan kecantikan hati dan kelembutan yang biasanya wanita Jawa gambarkan dengan murah senyum, berbicara dan berperilaku yang sopan santun. Warna biru kebaya yang berada di tenggah warna kuning juga memberikan kesan dingin dan tenang.

Proses produksi karya ini dilakukan pada saat sore hari sehingga cahaya yang didapat cenderung miring dan tidak terlalu keras, namun cahaya tambahan tetap diperlukan dalam karya ini untuk membuat model dan kebaya tetap netral. Karena white balance yang digunakan sekitar 8500$9000{ }^{\circ} \mathrm{K}$ yang membuat nuansa menjadi kekuningan, diperlukan tambahan berupa filter CTB $1 / 4$ pada kedua flash yang dipakai. Flash yang pertama pada posisi sudut $45^{\circ}$ dari atas dan diarahkan turun mengarah ke model dan posisi sudut kedua pada $135^{\circ}$ sebagai efek di bagian kiri model.

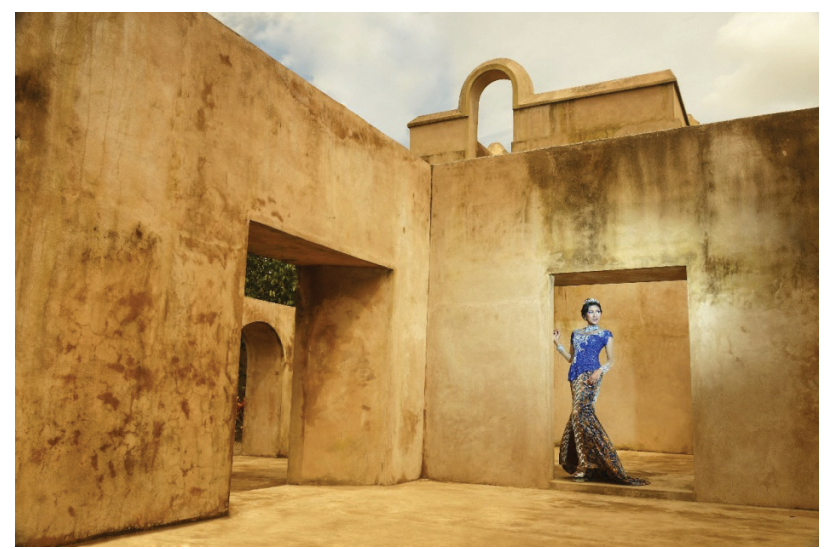

Karya foto 3 "Ayu"

$40 \mathrm{~cm} \times 60 \mathrm{~cm}$

Cetak foto glossy 2017

\section{SIMPULAN}

Fotografi fashion yang dipadukan dengan menampilkan latar belakang bangunan cagar budaya dengan komposisi pengambilan yang cukup luas bisa menjadi pilihan untuk menampilkan foto produk busana dalam hal ini busana kebaya. Pemotretan fashion retail seringkali hanya berfokus pada busana atau aksesoris yang ditawarkan dan lokasi pemotretan biasanya dalam ruangan atau studio. Karya-karya foto yang dihasilkan tidak sekadar menampilkan kebaya yang, namun juga ada nuansa dari warna perbedaan derajat Kelvin dengan latar belakang bangunan cagar budaya yang menjadi landmark kota Yogyakarta akan membuat foto-foto tersebut lebih dinamis dan menarik. Nuansa foto yang berlatar belakang bangunan cagar budaya tersebut bisa memberikan gambaran dan ketertarikan kepada penikmatnya tentang produk kebaya yang biasanya ditawarkan hanya untuk pernikahan dan prewedding. Latar belakang bangunan yang mendampingi foto produk kebaya milik amanda griya kebaya juga akan menarik minat konsumen. Promosi tidak hanya kebaya yang ditawarkan saja, tetapi secara tidak langsung akan menarik minat konsumen dari sisi latar belakang bangunan yang biasanya ditawarkan lewat foto-foto pariwisata.

Untuk menciptakan fotografi fashion sebuah produk busana kebaya dengan latar belakang bangunan cagar budaya diperlukan sebuah konsepyang matang. Hal ini berhubungan sekali dengan komunikasi visual, yaitu bagaimana merangkai makna dan tanda menjadi sebuah imaji yang dapat digunakan untuk menyampaikan pesan. Selain itu, juga dibutuhkan komunikasi yang baik sesama anggota tim dalam merealisasikan permintaan klien. Foto produk kebaya yang disandingkan 
dengan bangunan cagar budaya dalam visualnya digunakan perwujudan yang mengubah derajat Kelvin sehingga foto yang dihasilkan akan bernuansa biru atau dingn dan juga bernuansa kuning atau panas. Akan tetapi, pada produk kebaya yang ditawarkan akan tetap bernuansa normal atau daylight karena penggunaan filter CTO (color temperature orange) dan CTB (color temperature blue) yang akan tetap menjaga warna atau nuansa pada produk kebaya tetap normal. Teknik ini juga akan menambah point of interest pada kebaya yang ditawarkan sehingga audience akan lebih tertarik dengan produk kebaya yang ditawarkan.

Dalam melakukan pemotretan di outdoor harus dapat mengutamakan kekompakan dalam tim karena kekompakan tim sangat berpengaruh di lapangan untuk bisa mendapatkan hasil yang memuaskan. Selain itu, penggunaan cahaya tambahan juga harus disesuaikan dengan konsep outdoor yang ada. Komposisi dan angle pengambilan gambar turut memengaruhi minat audience dalam menikmati foto tersebut. Dalam penciptaan karya ini digunakan berbagai macam komposisi dan angle yang bervariasi agar foto yang dihasilkan tidak monoton sehingga audience tidak merasa bosan menikmatinya.

Kendala yang sedikit menyulitkan selama proses pembuatan karya ini mulai dari cuaca yang kurang menentu karena dominan pengambilan gambar dilakukan di luar ruangan (outdoor), lokasi yang izinnya sulit didapatkan untuk melaksanakan pemotretan, dan biaya untuk pemotretan cukup tinggi. Akan tetapi, walau selama proses melaksanakan pemotretan terdapat banyak kendala, hasil yang didapat tidak begitu mengecewakan dan cukup bisa memvisualkan produk Amanda Griya
Kebaya dengan latar belakang bangunan cagar budaya dan detail kebaya dapat jelas terlihat.

\section{KEPUSTAKAAN}

Abdi, Y. (2012). Photography from My Eyes. Jakarta: PT Elex Media Komputindo.

Adimodel. (2009). Lighting for Fashion Indoor Lighting. Jakarta: PT Elex Media Komputindo.

Apriyanto, M. F. \& I. (2012). Membaca Fotografi Potret: Teori, Wacana, dan Praktik. Yogyakarta: Gama Media.

Ardiansyah, Y. (2005). Tips \& Trik Fotografi. Jakarta: PT Grasindo.

Bajradaram, A. (2010). "Kebaya Modern pada Fotografi Fesyen". Institut Seni Indonesia Yogyakarta.

Danesi, M. (2012). Pesan, Tanda, dan Makna, "Buku Dasar Mengenai Semiotika dan Teori Komunikasi." Yogyakarta: Jalasutra.

Hall, S. (2003). "The Work Representation." Representation: CulturalRepresentation and Signifying Practices. London: Sage Publication.

Hasyim, H. (2009). Kebaya Encim Modern. Surabaya: Tiara Aksa.

Muller, S. (2011). Working with Flash. Retrieved June 5, 2017, from http: / / sheltonmuller.blogspot. co.id/2011/08/

Soedjono, S. (2006). Pot-Pourri Fotografi. Jakarta: Penerbit Universitas Trisakti.

Suleiman, A. H. (1983). Petunjuk untuk Memotret. Jakarta: PT. Gramedia. 